\title{
Pedagogisk takt synliggör komplexiteten i läraryrkets relationella dimension
}

\author{
Ann-Louise Ljungblad och Ilona Rinne \\ Göteborgs universitet
}

\section{SAMMANDRAG}

Utbildning har under de senaste decennierna dominerats av mätningar och rationalitet, vilket har bidragit till att relationella värden har åsidosatts. Syftet med denna artikel är att belysa relationella dimensioner av lärares arbete med utgångspunkt i resultaten i två empiriska klassrumsstudier (Ljungblad, 2016; Rinne, 2014) där pedagogisk takt har använts som teoretiskt analysverktyg ur Lövlies (2007) och van Manens $(1991,2015)$ perspektiv. I båda studierna utgör intersubjektivitet en central dimension. Genom att spegla studiernas resultat mot varandra framträder en djupare förståelse av komplexa relationella skeenden som lärare är involverade i och måste hantera. I artikeln diskuteras hur begreppet pedagogisk takt skapar möjligheter att synliggöra relationella dimensioner av läraryrket. Mer specifikt visar resultaten hur lärarna skapar en kon-takt med eleverna och synliggör relationella värden som möjliggör att elever kan framträda som subjekt. Vidare belyser artikeln hur pedagogisk takt kan bidra till att komma bortom det förgivettagna antagandet om att läraryrket är ett enkelt yrke. Sammanfattningsvis betonas vikten av existentiella värden i utbildning som en motvikt till att elever objektifieras i mätningarnas tidevarv.

Nyckelord: pedagogisk takt; lärare-elevrelation; relationell pegagogik; existentiella värden; klassrumsstudier

\begin{abstract}
Pedagogical tact makes visible the complexity in the relational dimension of the teacher profession

During the two past decades, in the field of relational pedagogy, the teacher-student relationship has been overshadowed by measurements and rationality. The aim of this article is to illustrate how pedagogical tact (Lövlie, 2007; van Manen, 1991, 2015) as an analytical tool can highlight new opportunities in classroom research, by visualising the relational dimension of teachers' work. The results are based on a comparative analysis of two classroom studies in which the notion of pedagogical tact has been used (Ljungblad, 2016; Rinne, 2014). Intersubjectivity is a crucial dimension in both studies. The analysis shows that pedagogical tact as an analytical tool can take us beyond the taken for granted assumption about teaching as an easy profession. The results reveal how the teacher seeks con-tact with the student. By exploring the relational and interpersonal aspects of teaching, existential dimensions of the teaching profession can be illuminated, and relational values
\end{abstract}

\footnotetext{
^Korrespondanse: Ann-Louise Ljungblad, e-post: ann-louise.ljungblad@gu.se 
which are of importance for students' growth can be visualised. In conclusion, the article discusses how pedagogical tact can contribute to the creation of human subjectification as a counterweight to students being objectified. Such a relational voice highlights existential values and the awareness of humanity.

Keywords: tactfulness; teacher-student relationship; relational pedagogy; existential values; classroom research

Mottatt: Oktober, 2019; Antatt: August, 2020: Publisert: Desember, 2020

\section{Inledning}

Vi lever i en global värld där en av utmaningarna är att möta mångfald, olikheter och skillnader (Säfström, 2005). Samhället och skolan uppvisar idag en större rörlighet än tidigare. Nya möten uppstår mellan människor, vilket i sin tur kräver ett nytänkande och en diskussion om relationella värdens betydelse för den pedagogiska praktiken. Dagens utbildningssystem som har fokus på mätningar av prov och betyg beskrivs av Biesta $(2006,2011,2017)$ som mätningarnas tidevarv. I den pedagogiska diskussionen om en sådan resultatinriktning har den rationella rösten en tendens att överskugga den relationella rösten, vilket är problematiskt då det leder till en förenklad bild av läraryrkets komplexitet.

Genom århundraden har pedagogiken orienterat sig mot existentiella frågeställningar (Saevi \& Biesta, 2020). I början av det nya millenniet har dock grundläggande existentiella aspekter av den pedagogiska praktiken fått träda tillbaka på grund av ökat fokus på det mätbara och instrumentella. Samtidigt finns det insikt om att betydelsefulla existentiella aspekter i undervisningen som handlar om att elever ges möjligheter att utvecklas som unika personer är omätbara, osäkra och oförutsägbara (Roberts, 2020).Vi behöver återigen uppmärksamma vad undervisning faktiskt handlar om (Masschelein, 2011). Existentiell pedagogik (Saevi \& Biesta, 2020) har bidragit till att forskningsfältet relationell pedagogik växte fram (Aspelin \& Persson, 2011; Bingham \& Sidorkin, 2004) med ett ökat intresse för existentiella frågor inom klassrumsforskning. Inom detta forskningsfält har lärare-elevrelationen studerats som en interpersonell relation utifrån olika perspektiv i skandinavisk forskning. Aspelin (1999) utforskade den interpersonella kommunikationen när lärare och elever möts ansikte mot ansikte. Resultatet av Aspelins studie visade på en tyst, mångfasetterad verklighet som ständigt pågår under ytan i klassrummet, vilket beskrevs som klassrummets mikrovärld. Vid tidpunkten runt det nya millenniet började också forskare som exempelvis Fibæk Laursen (2004) att problematisera föreställningen om den relationella dimensionen av läraryrket som en personlig egenskap hos läraren. Fibæk Laursen undersökte istället fenomenet autenticitet utifrån ett professionellt pedagogiskt perspektiv. Genom att utforska lärare som var kända för att utveckla en speciellt stödjande lärare-elevrelation konstaterade Fibæk Laursen att en autentisk lärare inte är någonting man $\ddot{a} r$ utan någonting man blir. På ett liknande sätt studerade Frelin 


\section{A.-L. Ljungblad \& I. Rinne}

(2010) hur lärares handlingar kan etablera och underhålla relationer. Denna relationella professionalitet framträder hos både erfarna och nyutbildade lärare som något av det svåraste i läraryrket. Samtidigt finns det föreställningar om hur lärarutbildningar relativt enkelt kan förbereda lärarstudenterna för deras kommande yrke. Som en motvikt till en sådan föreställning beskrivs undervisning som ett enormt svårt arbete som ser enkelt ut (Labaree, 2000). En del av komplexiteten handlar om hur lärare hanterar de mellanmänskliga aspekterna av mötet med eleverna, grundat i ett förgivettagande om att den relationella dimensionen av yrket är oproblematisk. I den här artikeln som går i linje med relationell klassrumsforskning problematiserar vi ett sådant förgivettagande.

Utifrån två empiriska klassrumsstudier (Ljungblad, 2016; Rinne, 2014) undersöker vi vad som relationellt och mellanmänskligt sker mellan lärare och elever när de möts i olika situationer i den pedagogiska praktiken. I syfte att studera komplexiteten i interpersonella relationer mellan lärare och elev valde forskarna begreppet takt (Lövlie, 2007; van Manen, 1991, 2015) som analytiskt verktyg. Taktbegreppet som har sitt ursprung i Herbarts pedagogiska filosofi, och fångar lärarens omdömesförmåga och visdom genom att förena teori och praktik, har sedermera utvecklats av Lövlie och van Manen. I klassrumsstudierna som ligger till grund för denna artikel utforskade Ljungblad (2016) med hjälp av taktbegreppet hur lärare relaterar till elever i undervisning och lyfte på så sätt fram en estetisk och kreativ dimension av yrket. Rinne (2014) förankrade lärares personliga och myndighetsutövande ansvar i taktbegreppet och belyste hur lärare balanserar dessa dimensioner i samband med förmedling av betyg i enskilda betygssamtal. Båda studierna har genom ett fördjupat analysarbete utifrån ett mellanmänskligt relationellt perspektiv utforskat dilemmasituationer som uppstår i praktiken. Med hjälp av takt studerades den svåra relationella balansgång som lärare ständigt står inför i det dagliga arbetet. Artikeln lyfter således fram den relationella rösten genom att bidra med ny kunskap grundad i empirisk forskning som belyser hur lärare hanterar komplexa relationella skeenden tillsammans med sina elever.

\section{Syfte}

Syftet i denna studie är att redogöra för hur takt (Lövlie, 2007; van Manen, 1991, 2015) kan tillämpas som ett analytiskt verktyg i empirisk klassrumsforskning för att synliggöra relationella värden och mellanmänskliga aspekter av det pedagogiska mötet mellan lärare och elever. Genom att sammanföra, jämföra och belysa klassrumsstudiernas resultat (Ljungblad, 2016; Rinne, 2014) kan den relationella dimensionen av läraryrket skildras och beskrivas med ny kunskap som är av betydelse för hur lärare kan hantera relationella skeenden tillsammans med sina elever. Vår forskning går således i linje med Biesta (2011) som understryker hur den relationella rösten ger utrymme för ett värdebaserat synsätt om vad som är pedagogiskt värdefullt för eleverna. 
Inledningsvis presenterar artikeln kortfattat relationell pedagogik som forskningsfält. Det följs av en redogörelse för taktbegreppets bakgrund och utveckling. Därefter beskrivs hur taktbegreppet har tillämpats i två empiriska studier för att belysa olika relationella aspekter av pedagogiska möten mellan lärare och elever. Vidare görs en jämförelse av studiernas empiriska material som synliggör generella mönster av interaktionen mellan lärare och elever. I jämförelsen av resultaten framträder ett liknande mönster i båda studierna som åskådliggör ett nytt relationellt värde - kon-takt. Mot bakgrund av detta resultat diskuteras slutligen komplexiteten i läraryrkets relationella dimension.

\section{Relationell pedagogik - ett ungt relationellt forskningsfält}

Artikeln tar sin utgångspunkt i relationell pedagogik (Bingham \& Sidorkin, 2004) som är ett ungt vetenskapligt fält. I antologin No Education Without Relation (Bingham \& SIdorkin, 2004) samlades en grupp forskare såsom Charles Bingham, Alexander Sidorkin, Gert Biesta, Barbara Stengel samt Frank Margonis och formulerade ett relationellt manifest. Författarna uppmärksammade åsidosättandet av relationella värden i utbildning och skrev fram ett nytt relationellt perspektiv. Det är ett synsätt som ser undervisning som relationsprocesser baserat på den ontologiska utgångspunkten att relationen är primär:

It relies on neither brute force of exclusion nor on romantic expectations. Schools must focus on human relations and address the core of the problem. A school with a vibrant community can avoid dangerous outbursts of vandalism and violence... We need to move from struggling against something to struggling for something. Pedagogy of relation offers an ideal of school based on the notion of democratic relations. (Bingham \& Sidorkin, 2004, s. 6)

Ett sådant relationellt pedagogiskt alternativ på undervisning och utbildning utgår från föreställningen om att relationella värden är grundläggande när lärare och elever möts och samverkar i klassrummen (Aspelin, 1999; Frelin, 2010; Lilja, 2013; Ljungblad, 2016, 2018, 2019; Rinne, 2014, 2017). Att studera relationer i olika kontexter är i sig inget nytt men relationell pedagogik som vetenskapligt fält strävar efter att på ett mer systematiskt sätt än tidigare utveckla nytt kunnande om läraryrkets relationella dimensioner, något som kan vara både subtilt och svårfångat i empirisk klassrumsforskning. Dessutom behöver det relationella fältet en tydligare definierad teoretisk utgångspunkt (Aspelin, 2017; Ljungblad, 2018, 2019). Under senare år har Nordiskt nätverk för relationell pedagogik, NoRP (Aspelin \& Johansson, 2017), samt ett internationellt nätverk Relation-Centered Education Network, RCEN, ${ }^{2}$ bildats. RCEN består av forskare, teoretiker och praktiker som understryker vikten av

1 https:/www.hkr.se/forskning/forskningsmiljoer/forskning-relationell-pedagogik-forp/norp — nordisktnatverk-for-relationell-pedagogik/

${ }^{2}$ https://sites.google.com/view/pedagogyofrelation/home 


\section{A.-L. Ljungblad E I. Rinne}

mellanmänskliga relationer i den pedagogiska praktiken. Nätverkets strävan är att genom framtida forskning bidra till att såväl erfarna som nyutexaminerade lärare uppmärksammar och utvecklar relationella dimensioner av läraryrket. En ytterligare strävan är att utveckla observationsscheman som kan användas i forskningsstudier av relationella skeenden mellan lärare och elever. RCEN är således ett komplement och ett alternativ till instrumentellt orienterade diskurser.

Denna artikel utgör ett kunskapsbidrag inom fältet relationell pedagogik genom att belysa hur pedagogisk takt kan tillämpas som analysverktyg i empirisk klassrumsforskning för att synliggöra relationella värden och mellanmänskliga aspekter av det pedagogiska mötet mellan lärare och elever.

\section{Pedagogisk takt - bakgrund och utveckling}

Begreppet pedagogisk takt introducerades av den pedagogiskt orienterade filosofen Johan Friedrich Herbart (1716-1841) i en föreläsningsserie om pedagogik år 1802 . Herbart var starkt influerad av de pedagogiska teorier och bildningskonceptioner som, i samband med den liberala demokratiska statens framväxt under 1700- och 1800-talen, formulerades av samtida tänkare såsom Kant, Rousseau, Herder, von Humboldt, Fichte och Schleiermacher (Uljens, 2017). Denna moderna tid präglades av djupgående förändringar i politisk syn, tänkesätt och livsåskådning, vilket också gav upphov till nya pedagogiska synsätt. Till skillnad från förmodern tid där framtiden var på förhand bestämd präglades den moderna, liberala staten av idén om framtiden som öppen och föränderlig, vilket medförde att bildningsprocessen kom att betraktas "som ett kontinuerligt kreativt framskridande utan på förhand givet mål” (Uljens, 2017, s. 63). Människan sågs därmed kunna påverka och forma sin egen framtid.

Idén om att individen medverkar till att utforma sig själv blev grundläggande i det pedagogiska förhållningssätt som uttrycks i Herbarts svåröversatta begrepp Bildsamkeit. ${ }^{3}$ Bildsamkeit utgör en grundläggande aspekt av begreppet takt och riktar fokus mot individens frihet (Lövlie, 2007) samt människans förmåga att reflektera över sitt handlande och sina erfarenheter (Uljens, 2017). Även fostran är ett centralt begrepp i Bildsamkeit och Herbart förankrar fostran i pedagogiska teorier som genomsyras av en tilltro till möjligheten att med hjälp av undervisning forma och bilda människan genom en moralisk uppfostran (Kenklies, 2012; Uljens, 2014). Människor behöver följaktligen lära sig att värdera moraliska handlingar genom att använda sitt omdöme. Herbart betonar dock att det inte går att formulera allmängiltiga regler för moraliskt handlande i varje enskilt fall, eftersom varje specifik situation kan uppfattas på olika sätt. I detta sammanhang introducerar han begreppen logisk och estetisk nödvändighet. I det förstnämnda baseras det moraliska handlandet på förnuftet och i det sistnämnda

${ }^{3}$ Uljens (1998) poängterar att tolkningarna av vad Herbart kan ha menat med begreppet Bildsamkeit varierar. 
på det estetiska omdömet (Kenklies, 2012; Lövlie, 2007). I ett pedagogiskt sammanhang innebär det att eleven behöver lära sig reflektion och omdöme, eftersom intryck och företeelser varken går att visa empiriskt eller logiskt argumentera för. Lärarens roll inbegriper då att stödja eleven att reflektera över situationen och använda sin omdömesförmåga för att anpassa sitt handlande. Ett sådant handlande sker enligt Herbart med hjälp av takt.

Ytterligare en grundläggande aspekt i Herbarts beskrivning av taktbegreppet berör ett av pedagogikens fundamentala problem, nämligen uppdelningen mellan teori och praktik (Kenklies, 2012; Lövlie, 2007; van Manen, 2015). Herbart betonar att det pedagogiska handlandet inte fullt ut kan beskrivas med hjälp av olika teorier och riktlinjer. Samtidigt måste läraren veta vad som är lämpligt att göra och säga i den pedagogiska praktiken. Pedagogisk takt är enligt Herbart det begrepp som fångar lärarens förmåga att i stunden kunna avgöra vad som är det bästa för eleven. Takt handlar således om en omedelbar handling och är därmed inte ett resultat av tänkande eller kognition. Herbart urskiljer taktbegreppet mot bakgrund av möjliga förhållningssätt som läraren kan anta i uppdelningen mellan teori och praktik (Kenklies, 2012) och understryker att humanvetenskap inte kan förklaras utifrån naturvetenskapens lagar. Här introducerar Herbart istället ett förhållningssätt som omfattas av pedagogisk takt. Det innebär att moraliska principer inte kan vila på lärarens egna teorier eller observationer. Det är snarare lärarnas erfarenheter och tilltro till sin egen uppfinningsrikedom som gör det möjligt att "i stunden fatta de enkla beslut som varje ögonblick kräver" (Herbart citerad i Lövlie, 2007, s. 92). Takt kan således inte förklaras med teknokratiska modeller. Det är ett komplext, icke-dualistiskt begrepp som förenar teori och praktik. Det i sin tur gör att takt är ett intressant begrepp som kan belysa relationella värden och synliggöra lärarens omdömesförmåga, något som är relativt outforskat i empiriska klassrumsstudier. Som nämnts inledningsvis präglas vår tid av en allt större tilltro till det rationella och mätbara och allt mindre utrymme ges åt det mellanmänskliga och det omätbara (Bornemark, 2018; Liedman, 2011), vilket medför att relationella värden som omfattas av pedagogisk takt har en tendens att bli osynliga.

\section{Takt enligt Lövlie}

Lars Lövlie (2007) utgår ifrån Kants humanitet och beskriver takt som "ett sätt att vara och belysa förhållandet till världen och den andre" (s. 78). I diskussionen om en human och demokratisk livsform framhåller Lövlie hur begreppen respekt, tillit och erkännande oftast placeras i bakgrunden. Lövlie understryker betydelsefullheten av dessa begrepp och lyfter dessutom fram begreppet takt. Genom att ta utgångpunkt $\mathrm{i}$ takt som ett sätt att vara i världen belyser författaren samtidigt förhållandet till andra människor. Grunden är den mänskliga gemenskapen där takten blir synlig som ett allmänmänskligt gensvar och som en följsamhet mellan deltagarna i det sociala samspelet. Takten framträder således mer som en allmän förmåga mellan människor än 


\section{A.-L. Ljungblad \& I. Rinne}

som en enskild personlig förmåga. I en allmänmänsklig värld får takt sitt berättigande av människors kommunikation och deltagande. "Den plats där världen framträder för deltagarna är allas plats” (s. 93). Denna gemensamma mötesplats är mellanrummet, ansikte mot ansikte, där takten förnimms som atmosfären mellan människor. En gemensam hållning utgör därmed horisonten för att kunna tala om takt. Utifrån våra livserfarenheter verkar vi också veta och känna in vad takt är när vi möter den.

Lövlie (2007) skildrar hur takt vanligtvis beskrivs som en psykisk egenskap där en person kan tolka en annan persons inre liv. Lövlies takt går bortom det psykologiska och det kognitiva och visar istället på ett estetiskt förhållande som är subjektivt. I motsats till det kognitiva och objektiva sker det subjektiva spontant i nuet utan reflektion. När det estetiska får tala framträder ett estetiskt modus grundat i sinnliga erfarenheter. ${ }^{4}$ Ett sådant sätt att se på takt tar oss förbi diskursen om den reflekterande praktikern (Schön, 1995) som reflekterar över det pedagogiska tänkandet $\mathrm{i}$ handlingens stund. Erlandson (2007) problematiserar bärkraften i Schöns begrepp reflection-in-action och är tveksam till om det klarlägger professionella praktikers yrkesskicklighet. Då begreppet tar utgångspunkt i att kroppen lyder när medvetandet styr hävdar författaren att det inte helt kan klargöra lärarnas handlande i praktiken. Med stöd av Deweys (1991) pragmatiska hållning lyfter Erlandson istället fram vad som sker när reflektionen tar sin början. Plötsligt uppstår en känsla av osäkerhet eller tvekan som vi känner med våra sinnen. Ur denna sinnliga känsla startar sedan vår reflektion. Lövlies takt får en liknande innebörd då den grundas i upplevelser av våra sinnen och estetiska erfarenheter och inte utifrån medvetna reflektioner. Följaktligen ingår takt $\mathrm{i}$ en human och demokratisk livsform och visar sig istället som "ett sätt att vara, snarare än som en förmåga, metod eller ett visst tillvägagångssätt" (Lövlie, 2007, s. 100). I undervisningen kan en öppen hållning i nuet bli synlig när läraren känner av om metoder inte fungerar och istället känner in hur det är fatt med eleven. Genom Lövlies sätt att beskriva takt skapas förståelse för människors handlande när det inte finns regler, då det estetiska som är grundat i sinnliga kroppsliga erfarenheter kommer före metoder och regler. Samtidigt lyfter Lövlie (2015) fram i ljuset vikten av en pedagogisk fantasi då människor inte kan instrueras i takt.

När Lövlie (2007) belyser taktfullhet pekar han inte främst på personers sociala färdigheter utan på begreppet humanitet. Centralt är förhållandet till den andre och i centrum hamnar mellanmänskliga relationer, kommunikation och deltagande. I mötet med eleven kan lärarens sociala sätt att vara skifta fokus från "Vad" eleven är till en undran om "Vem" eleven är (von Wright, 2000, 2006). I ett sådant skifte går lärarens blick från en punktuell position som ser eleven som autonom och avskild där svaret går att finna i personens egenskaper, till att lärarens blick antar en relationell position där eleven kan framträda som ett handlande subjekt. Vår pedagogiska blick blir därigenom framåtriktad och vänder sig mot det som eleven ger uttryck för $\mathrm{i}$

${ }^{4}$ I Kants beskrivning baseras det icke-reflekterande på estetiska grunder. Estetiken grundas således inte $i$ en logisk process utan ses som en stämning där det sköna sätts i rörelse (Lövlie, 2007, s. 96). 
öppna och utforskande samtal (Ljungblad \& Lennerstad, 2011). Rent konkret kan det nya och oberäkneliga som elever skapar i undervisningen framträda som överraskningar. I praktiken blir det särskilt betydelsefullt hur lärares pedagogiska takt tar sig uttryck i dilemmasituationer som uppstår i undervisningen. Genom att utforska relationella dimensioner av undervisningen kan både existentiella aspekter av läraryrket belysas samtidigt som det skapar en relationell utvidgad förståelse av situerad undervisning.

\section{Takt enligt van Manen}

Ytterligare ett sätt att studera takt i en pedagogisk kontext har utvecklats av Max van Manen $(1991,2015)$ utifrån en fenomenologisk och hermeneutisk teoretisk grund. Enligt van Manen har takt en egen epistemologisk och ontologisk struktur där omtanke och omsorg är centralt. Van Manen utgår ifrån Herbarts taktbegrepp som förenar teori och praktik och understryker att takt inte kan tillägnas med hjälp av särskilda tekniker eller instruktioner. Relaterat till undervisning betonar van Manen bland annat den kroppsliga dimensionen av pedagogisk takt. Den synliggörs i ordets etymologi då takt härstammar från latinets tangere som betyder beröra. Engelskans tactful får därmed betydelsen full av takt, det vill säga full av beröring: "To teach is to touch and to be touched" (van Manen, 2015, s. 103). Med utgångspunkt i fenomenologin där kropp och själ utgör en enhet som förenas i den levda kroppen kan beröring inte avgränsas enbart till fysikalitet, utan inbegriper hela den levda kroppen (Merleau-Ponty,1962/2002). Inom fenomenologin betonas dessutom den kroppsliga samexistensen. När vi föds blir vi inkastade i en social värld där vi är "inflätade i en socialitet med andra" (Thörgesen, 2003, s. 55). Vårt agerande har alltid en påverkan på andra, inte minst känslomässigt. Därför kräver pedagogiskt handlande finkänslighet. I van Manens beskrivning av pedagogisk takt riktas således fokus mot lärarens anpassningsförmåga, omsorg om eleven samt lyhördhet för elevens behov. Lärare behöver utveckla ett pedagogiskt seende för att synliggöra det osynliga och för att kunna avgöra vad som är bäst för den specifika eleven. Den taktfulla läraren besitter således en förkroppsligad förmåga att snabbt kunna orientera sig i situationen och anpassa sitt agerande till den.

Van Manens (1991, 2005) takt är ett icke-kognitivt, förkroppsligat begrepp som varken går att återge med en kognitiv diskurs eller beskriva utifrån standardiserade former. Takt kan därför vara svårt att definiera men vissa utmärkande drag kan urskiljas. För det första riktar sig takt mot det specifika och det partikulära i varje situation och manifesterar sig själv som omedelbar handling. För det andra går takt varken att planera eller reglera och kan bara tillägnas genom handling. Det i sig medför att det kan ta tid att utveckla ett taktfullt handlande. Vidare bygger takt på intuitiv känslighet för att varje individ är unik. Pedagogisk taktfullhet kännetecknas framförallt av ett ödmjukt handlande i situationen och öppenhet inför andra möjliga tillvägagångssätt. Det i sin tur leder också till tvivel om det rätta handlandet. 


\section{A.-L. Ljungblad E I. Rinne}

\section{Taktbegreppet i empirisk klassrumsforskning}

Ljungblads (2016) och Rinnes (2014) klassrumsstudier utforskade relationella aspekter av interpersonell interaktion i skilda kontexter såsom undervisning och betygsättning med hjälp av pedagogisk takt som teoretiskt analysverktyg. I de aktuella studierna studerades olika aspekter av takt där intersubjektivitet utgör en central dimension. Lövlies taktbegrepp användes som analysverktyg i Ljungblads (2016) klassrumstudie Takt och hållning - en relationell studie om det oberäkneliga i matematikundervisningen. ${ }^{5}$ Syftet med studien var att öppet utforska hur lärare-elevrelationer empiriskt tar sig uttryck i undervisningen. Van Manens taktbegrepp tillämpades som analysverktyg i Rinnes (2014) klassrumsstudie Pedagogisk takt $i$ betygssamtal. ${ }^{6}$ Syftet med studien var att utforska lärares och elevers förståelse av betyg så som den visar sig i enskilda betygssamtal ${ }^{7}$ på gymnasiet.

Metodologiskt utgick båda klassrumsstudierna ifrån ett öppet utforskande av relationella aspekter av interpersonell interaktion mellan lärare och elever. Båda forskarna använde sig av liknande empiriska underlag och analysprocess. Efter avslutat fältarbete genomfördes djupgående mikroanalys av interaktionen med stöd av Lövlies (2007) och van Manens (1991, 2015) taktbegrepp. Det finns likheter i dessa taktbegrepp såsom att takt beskrivs som ett omedelbart handlande i nuet. Samtidigt finns skillnader som ligger till grund för forskarnas olika teoretiska val. Lövlie tar utgångspunkt ur humanitet och demokrati och betonar människors deltagande i gemenskap. Fokus riktas mot mellanrummet mellan lärare och elev, ansikte mot ansikte, där intersubjektiviteten utforskas. Lövlies taktbegrepp går bortom det psykologiska och reflekterande och istället framträder en sinnlig följsamhet som går att studera i lärarens gester, tonfall, blickar och mimik. Van Manens beskrivning av taktbegreppet är förankrat i fenomenologi och fokuserar omtanke, omsorg, lyhördhet samt anpassningsförmåga. Lärarens takt förstås med utgångspunkt i den levda kroppen, som innebär att kropp och själ utgör en enhet (Merleau-Ponty, 1962/2002). Takt är därmed ett icke-kognitivt, förkroppsligat begrepp som bygger på lärarens finkänslighet och förmåga att avgöra vad som är bäst för eleven i varje specifik pedagogisk situation. En avgörande aspekt för forskarna var att Ljungblad valde att studera intersubjektiviteten

\footnotetext{
${ }^{5}$ Avhandlingen återfinns inom fältet inklusion och är inspirerad av Biestas $(2001,2011)$ syn på inklusion, det oberäkneliga. I studien deltog 4 matematiklärare och 100 elever från grundskola, gymnasiesärskola och gymnasieskola. Tidigare elever till de deltagande lärarna betonade att i dessa undervisningsmiljöer möter lärarna eleverna på ett särskilt tryggt och utvecklande sätt. Sökljuset riktades mot hur lärarna relaterar till sina elever när de undervisar. Studien tog sin utgångspunkt i barnkonventionen (UD, 2006) och barns rättigheter att i undervisning ingå i demokratiska relationer, demokratisk i bemärkelsen att få framträda som unik person.

${ }^{6}$ Det empiriska underlaget i studien utgjordes av 149 videoinspelade betygssamtal med nio gymnasielärare och deras elever.

${ }^{7}$ Betygssamtal är enskilda samtal mellan lärare och elev. Till skillnad från utvecklingssamtal är dessa samtal inte obligatoriska.
} 
i sig med hjälp av Lövlies taktbegrepp, medan Rinne valde att studera den intersubjektiva förståelsen utifrån en kroppslig samexistens i ett fenomenologiskt perspektiv baserat på van Manens taktbegrepp. I och med att de empiriska studierna öppet utforskade pedagogisk taktfullhet i olika kontexter är det möjligt att här i artikeln synliggöra och problematisera olika relationella aspekter av läraryrket.

\section{Taktbegreppet - ett kraftfullt analysverktyg}

Studiernas resultat (Ljungblad, 2016; Rinne, 2014) fördes samman i syfte att belysa hur begreppet pedagogisk takt kan tillämpas som analytiskt verktyg i empirisk forskning för att synliggöra relationella värden och mellanmänskliga aspekter av pedagogiska möten mellan lärare och elever. Inledningsvis analyseras likheter och skillnader i resultaten utifrån Lövlies (2007) och van Manens $(1991,2015)$ taktbegrepp.

När Ljungblad (2016) utforskade hur lärarna relaterar till sina elever blev en följsamhet synlig som kan observeras i lärarens gester, blickar, mimik och tonfall. I undervisningsögonblicket är lärarna fokuserade på det didaktiska innehållet och är inte medvetna om hur de relaterar till sina elever. Mikroanalysen visar hur lärarnas pedagogiska takt framträder i olika taktbyten, som exempelvis i en för eleven sårbar situation när läraren böjer sig fram i en inbjudande gest och söker ögonkontakt med eleven och samtidigt sänker tonfallet. Det är således en oberäknelig takt grundad i estetiska erfarenheter som improviseras i stunden. Rent konkret handlar pedagogisk taktfullhet om hur läraren söker finna balansen, takten, i mötet med eleven, ansikte mot ansikte. Med hjälp av videokameran kunde forskaren fånga svåra, dagliga dilemmasituationer som läraren måste hantera. Resultaten synliggör hur lärarna ständigt söker en taktfull balansgång i olika situationer. I mötet med en grupp elever som arbetar med samma uppgift kan lärarens pedagogiska taktfullhet ta sig skilda uttryck mot de olika eleverna. Det kan förstås utifrån att den pedagogiska taktfullheten möter såväl elevernas varierande behov av stöd som att eleverna är olika som personer. Barn skiljer sig åt och i den konkreta situationen förnimmer lärarna atmosfären med sina sinnen och känner av vad som fungerar $i$ stunden med olika elever. När eleverna ständigt får möta en pedagogisk taktfullhet från läraren utvecklas tillitsfulla och respektfulla lärare-elevrelationer. Ett ytterligare bärande resultat lyfter fram att det relationellt inte är någon skillnad på hur lärarna relaterar till elever oavsett ålder, skilda skolformer eller olika nivåer $i$ ämnet. Det generella resultatet visar också att de deltagande lärarna har utvecklat en hög beredskap för att möta oberäkneliga skeenden i undervisningen (Biesta, 2001, 2011). Mikroanalys av dilemmasituationer skildrar hur lärarna hanterar komplexa undervisningssituationer med en öppen och tolerant hållning. När eleverna talar med sina unika röster och frambringar något nytt avstår lärarna ifrån omdömet och lyssnar nyfiket. I dessa undervisningsmiljöer framträder dessutom en dubbel ansvarshållning genom att lärarna tar ansvar för såväl undervisningens innehåll som för relationens kvalitet. Det leder till att eleverna inte blir bärare av undervisningens problem. 


\section{A.-L. Ljungblad \& I. Rinne}

Sammanfattningsvis ger resultatet en djupare relationell förståelse för att lärarens pedagogiska taktfullhet kan skapa rum för elever att få framträda som subjekt och tala med sina unika röster.

Med hjälp av videoinspelningar kunde sublima dimensioner av mellanmänsklig interaktion fångas i Rinnes (2014) studie. Analysen tog sin utgångspunkt i Merleau-Pontys (1962/2002) beskrivning av den levda kroppen, vilket medförde att både verbala och icke-verbala uttryck beaktades. Mest slående i ett tidigt skede av analysprocessen av den rika empirin var betygssamtalens känslomässiga laddning. Både lärare och elev uttryckte oro och spänning särskilt i de samtal där betyget har ett högt värde för eleven. Den känslomässiga dimensionen utgjorde därför utgångspunkten i den vidare analysen och öppnade därmed för ett synliggörande av lärarens lyhördhet och finkänslighet gentemot eleven. Resultaten visar att lärare anpassar sitt handlande till vad som är mest pedagogiskt lämpligt för den specifika eleven. Exempelvis kan lärare sätta ett högre betyg vid så kallade gränsfall med motiveringen att det högre betyget kommer att sporra eleven i nästkommande kurs. Ett sådant agerande strider mot den formella beskrivningen av betygsättning och kan rentav uppfattas som felaktigt. Utifrån ett mellanmänskligt perspektiv kan lärares agerande däremot förstås som omtanke och omsorg om eleven. Därmed inte sagt att lärare sätter betyg för att tillgodose elevers önskemål. Genom att förankra analysen i begreppet pedagogisk takt kunde en mängd problematiska aspekter av betygsättningsuppdraget synliggöras. Inte minst visar studien hur lärare balanserar mellan det personliga och det myndighetsutövande ansvaret, vilket inte sällan medför att de upplever existentiella dilemman när dessa dimensioner hamnar på kollisionskurs. Med hjälp av begreppet pedagogisk takt upphävs tudelningen mellan teori och praktik och en levd dimension blir synlig, vilket i sin tur bidrar till nya möjligheter att problematisera och nyansera lärares betygsättningsuppdrag.

Sammantaget visar resultaten när studiernas resultat förts samman att pedagogisk takt (Lövlie, 2007; van Manen, 1991, 2015) är ett kraftfullt analysverktyg som belyser olika existentiella aspekter av den relationella dimensionen av läraryrket. Våra empiriska studier skapar insikt om att det krävs ett fördjupat mikroperspektiv för att utforska existentiella aspekter av pedagogiska möten mellan lärare och elever, där man bryter ner och analyserar mindre delar för att därefter summera interaktionen mellan lärare och elever i täta beskrivningar. I utforskandet av pedagogisk takt synliggörs bland annat följande resultat: (i) hur lärares lyhördhet, finkänslighet och följsamhet tar sig uttryck, (ii) hur lärare hanterar olika dimensioner av läraryrket, (iii) hur lärare möter och svarar an på olika existentiella dilemman som kan uppstå i interaktionen med eleverna, (iv) hur existentiella värden såsom förtroende, tillit och respekt växer fram över tid i lärare-elevrelationen, (v) hur estetisk skönhet kan framträda som en följsamhet samt upplevas som en atmosfär i ett personligt möte mellan människor. Utifrån en existentiell förståelse av pedagogik är liknande relationella aspekter av mellanmänsklig interaktion således svårfångade rent empiriskt och dessutom komplexa att beskriva i ord. 


\section{Bortom det förgivettagna}

Hur takt kan öppna för nya pedagogiska perspektiv på empirisk klassrumsforskning som tar oss bortom det förgivettagna synliggörs i nästa analysfas. Den jämförande analysen av studiernas rika resultat tar oss bortom vissa förgivettaganden om läraryrket. I Ljungblads (2016) studie om hur lärare relaterar till elever i undervisningen utgörs det förgivettagna av att fokus enbart riktas mot hur läraren undervisar ett ämnesinnehåll. I Rinnes (2014) studie om betygssamtal förstås det förgivettagna som ett oproblematiskt förhållningssätt till betygsättning i allmänhet och förmedlande av betyg till en elev i synnerhet. Bortom det förgivettagna kan således betydelsefulla relationella värden framträda som synliggör mellanmänskliga aspekter av vad som sker när lärare och elever möts.

Genom att rikta sökljuset mot lärares pedagogiska taktfullhet skapas en mångfasetterad fördjupad förståelse av hur takten ständigt är närvarande i mötet mellan lärare och elever. När lärarnas följsamhet utforskas framträder ett generellt resultat, nämligen hur lärarna söker kon-takt med eleven, det vill säga en takt med eleven. ${ }^{8}$ Det är en takt mellan lärare och elev som ömsesidigt berör båda parter och som i sin oförutsägbarhet ständigt framträder i olika pedagogiska situationer. Läraren söker förstå eleven som subjekt - Vem eleven är, som en motvikt till att ständigt mätas och bedömas som ett objekt - Vad man är som elev (von Wright, 2000, 2006). Här framträder således ett relationellt meningsskapande där läraren som person möter eleven som person (Ljungblad, 2016, 2018, 2019; Rinne, 2014, 2017). Analysen visar vidare på vikten av att läraren utvecklar en pedagogisk känslighet och ett pedagogiskt seende i syfte att kunna känna in och avgöra vad som är bäst för den enskilda eleven i olika pedagogiska kontexter. Utforskandet av pedagogisk taktfullhet synliggjorde dimensioner av det förgivettagna och skapade en fördjupad relationell förståelse av situerad undervisning (Ljungblad, 2016). När läraren släpper sin lektionsplanering och improviserar framträder lärarens pedagogiska takt som en sinnlig estetisk konstform, som i sin tur kräver en viss pedagogisk fantasi (Lövlie, 2015). I linje med en pedagogisk fantasi blir också en estetisk och kreativ dialog mellan lärare och elev synlig snarare än ett traditionellt normativt samtal. Det kan förstås som en inbjudan till ett pedagogiskt fritt skapande som inte är bundet till särskilda metoder utan är knutet till gemenskap och humanitet. Utforskandet av takt synliggjorde också hur lärare hanterar det spänningsfält som uppstår mellan lärarens myndighetsutövande och personliga ansvar när lärare ska förmedla ett betyg till eleven (Rinne, 2014, 2017). Även här tar oss takt bortom det förgivettagna genom att fånga intensiva relationella skeenden som tidigare varit oupptäckta. När lärare och elev möts ansikte mot ansikte behöver lärare följaktligen hantera en mängd olika aspekter som handlar om ifrågasättande, reaktioner samt känslor såsom glädje, besvikelse och frustration. Här framträder takten i en balansakt där läraren behöver vara följsam och uppmärksamma det partikulära i varje

\footnotetext{
${ }^{8}$ Con (latin) - med.
} 


\section{A.-L. Ljungblad \& I. Rinne}

situation, vilket i sin tur leder till att det kan uppstå en konflikt mellan vad läraren skulle vilja göra och vad läraren kan göra.

Sammanfattningsvis visar resultatet med stöd av taktbegreppet som analysverktyg på följande mellanmänskliga aspekter: (i) dynamiken och komplexiteten i pedagogiska möten av olika slag, (ii) upphävandet av tudelningen mellan teori-praktik genom att synliggöra den levda dimensionen av yrket, (iii) hur pedagogisk takt möjliggör att en kon-takt skapas mellan lärare och elev över tid, (iv) ett pedagogiskt nytänkande som tar avstånd från en objektifierande syn på eleven och skapar möjligheter för hur eleven kan framträda som subjekt, (v) sist men inte minst framträder pedagogisk takt som ett pedagogiskt relationellt grundfundament i läraryrket.

\section{Diskussion}

Läraryrkets levda relationella dimension är en del av en mångfasetterad existentiell pedagogik (Saevi \& Biesta, 2020). Genom att utforska lärarens pedagogiska taktfullhet som ständigt berör eleverna (Ljungblad, 2016; Rinne, 2014) framträder inte ett romantiskt skimmer där pedagogisk takt är en enkel lösning på alla problem. Däremot har taktbegreppet en potential att visa på den komplexa verklighet som lärare måste hantera, samtidigt som vissa förgivettaganden som kännetecknar läraryrket kan problematiseras. Den rika empirin i klassrumsstudierna åskådliggör hur läraryrket innefattar ett hårt relationsarbete där det inte finns enkla lösningar. Pedagogisk taktfullhet är alltid omedelbar, improviserad och situationsbunden. Resultatet ger insikt om vikten av att läraren är följsam, sensitiv, inlyssnande, ger respons och skapar möjligheter för eleverna att framträda som subjekt. I den asymmetriska maktrelationen mellan lärare och elev har läraren också ett professionellt ansvar för relationens kvalitet. Medvetenheten om den relationella komplexiteten ger samtidigt insikt om att lärare har ett frirum, nämligen att välja hur man relaterar till sina elever ansikte mot ansikte (Ljungblad, 2016).

I dagens pedagogiska debatt måste vi utifrån barns perspektiv (UD, 2006) ställa oss frågan vad som är pedagogiskt värdefullt för eleverna. Det är uppenbart att mätningarnas tidevarv (Biesta, 2006, 2011, 2017) inte fångar relationella värden, och inom rådande effektivitetsdiskurs riskerar dessutom de relationella värdena att utarmas. När människan objektifieras och formas efter institutionella ramar finns ingen plats för barn och unga att framträda som handlande subjekt. Ett sådant rationellt synsätt är djupt problematiskt - om vi tappar bort mänskliga värden tappar vi också synen på barnet som människa. Det som är betydelsefullt ur ett relationellt perspektiv är inte enkelt mätbart utan handlar om att elever ges möjlighet att delta i meningsfulla relationer; där eleven blir sedd som den person hen är och ges möjlighet att framträda som subjekt, tala med sin unika röst och även lyssna till andras röster (Biesta, 2011; Säfström, 2005). Ett sådant skifte från ett effektbaserat synsätt till ett värdebaserat synsätt på undervisning kan åskådliggöra relationella värden som är av betydelse för elevernas växande och utveckling. 
Taktbegreppet som analysverktyg i empirisk forskning bidrar till en ökad förståelse för och kunskap om mellanmänskliga aspekter av pedagogiska möten mellan lärare och elever. När lärare utvecklar flexibilitet, följsamhet och pedagogisk taktfullhet kan ett nytt relationellt värde i lärare-elevrelationen växa fram. Över tid skapas en kon-takt mellan lärare och elev som ömsesidigt berör båda parter och som i sin oförutsägbarhet ständigt framträder i olika pedagogiska situationer. En sådan kon-takt kan skapa trygghet, förtroende och tillit som är grundläggande för det gemensamma arbetet och för hållbara lärare-elevrelationer (Aspelin, 1999; Frelin, 2010; Lilja, 2013; Ljungblad, 2016; Rinne, 2014). Lärarens pedagogiska taktfullhet är således ett relationellt grundfundament i läraryrket som behöver utforskas ytterligare. Relationell pedagogik (Aspelin \& Persson, 2011; Bingham \& Sidorkin, 2004) är ett vetenskapligt fält som studerar mellanmänskliga relationer och synliggör betydelsefulla relationella aspekter av vad som är pedagogiskt värdefullt för eleverna. Trots att relationella värden är svårfångade och subtila i empirisk forskning vill vi understryka behovet av mer forskning om läraryrkets relationella dimensioner som kan utveckla ett relationellt kunskapsområde inom lärarutbildning. Vidare behövs fortbildning så att lärare i praktiken kan utveckla en pedagogisk taktfullhet och en djupare förståelse för vad det innebär att vara och verka som lärare (jfr. Aspelin \& Persson, 2011; Ljungblad, 2016, 2018, 2019; Rinne, 2017).

Avslutningsvis vill vi hävda att det är angeläget att lyfta fram den relationella rösten i dagens pedagogiska debatt. Genom att rikta sökljuset mot pedagogikens existentiella dimensioner betonas respekten för människovärdet - och vikten av att inte tappa blicken från att pedagogiska möten mellan lärare och elever är mellanmänskliga möten. På så sätt kan vi utgöra en motvikt till ett instrumentellt förhållningssätt till utbildning och gemensamt återupprätta värden som humanitet och medmänsklighet.

\section{Författarpresentation}

Ann-Louise Ljungblad is a Senior lecturer at the Department of Education and Special Education, University of Gothenburg, Sweden. She is a Ph. D in Pedagogy. Her research interests are in the field of Inclusive Education, Relational Pedagogy, Children's Rights and Mathematical Difficulties. She has a special interest in empirical classroom studies in the field of diversity, participation, accessibility and equity. Latest publication: Ljungblad, A-L. (2019). Pedagogical Relational Teachership (PeRT) - A multi-relational perspective. International fournal of Inclusive Education. doi.org/10.1080/13603116.2019.1581280

ann-louise.ljungblad@gu.se

Box 300, 40530 Gothenburg, Sweden

(iD https://orcid.org/0000-0002-8148-9172

Ilona Rinne is a Senior lecturer at the Department of Pedagogical, Curricular and Professional Studies, University of Gothenburg, Sweden. She is a Ph. D in General Didactics. Her research interests are in the field of Assessment, Teacher Education, 


\section{A.-L. Ljungblad E I. Rinne}

Phenomenology and Hermeneutics and Relational Pedagogy. Latest publication: Rinne, I. (2020). Pedagogic Being in a Neoliberal School Market: Developing Pedagogical Tact Through Lived Experience. Phenomenology E Practice, 14(1), 105-1 17. ilona.rinne@gu.se

Box 300, 40530 Gothenburg, Sweden

\section{Referenser}

Aspelin, J. (1999). Klassrummets mikrovärld (Doktorsavhandling). Stockholm/Stehag: Symposion.

Aspelin, J. (2017). In the heart of teaching. A two-dimensional conception of teachers' relational competence. Educational Practice and Theory, 39(2), 39-56. https://doi.org/10.7459/ept/39.2.04

Aspelin, J. \& Persson, S. (2011). Om relationell pedagogik. Malmö: Gleerups.

Aspelin, J. \& Johansson, L. (Red.). (2017). Temanummer Relationell pedagogik. Pedagogisk forskning $i$ Sverige, 22(3-4), 159-165.

Biesta, G. (2001). Preparing for the incalculable. Deconstruction, justice, and the question of education. I G. Biesta \& D. Egéa-Kuehne (Red.), Derrida E Education (s. 32-54). London: Routledge.

Biesta, G. (2006). Bortom lärandet. Demokratisk utbildning för en mänsklig framtid. Lund: Studentlitteratur.

Biesta, G. (2011). God utbildning $i$ mätningens tidevarv. Stockholm: Liber.

Biesta, G. (2017). Education, measurement and the professions: Reclaiming a space for democratic professionality in education, Educational Philosophy and Theory, 49(4), 315-330. https://doi.org/10.1080/0 0131857.2015 .1048665

Bingham, C. \& Sidorkin, A. (2004). No education without relation. New York: Peter Lang.

Bornemark, J. (2018). Det omätbaras renässans. Stockholm: Volante.

Dewey, J. (1991). How we think. New York: Prometheus Books.

Erlandson, P. (2007). Docile bodies and imaginary minds. On Schön's reflection in action (Doktorsavhandling). Göteborg: Acta Universitatis Gothoburgensis.

Fibæk Laursen, P. (2004). Den autentiska läraren. Bli en bra och effektiv undervisare - om du vill. Stockholm: Liber.

Frelin, A. (2010). Teachers' relational practices and professionality (Doktorsavhandling). Uppsala: Uppsala universitet.

Kenklies, K. (2012). Educational theory as topological rhetoric: The concepts of pedagogy of Johann Friedrich Herbart and Friedrich Schleiermacher. Studies in Philosophy and Education, 31(3), 265-273. https://doi. org/10.1007/s11217-012-9287-6

Labaree, D. F. (2000). On the nature of teaching and teacher education: Difficult practices that look easy. fournal of Teacher Education, 51(3), 228-233. https://doi.org/10.1177/0022487100051003011

Liedman, S-E. (2011). Hets! En bok om skolan. Stockholm: Albert Bonniers Förlag.

Lilja, A. (2013). Förtroendefulla relationer mellan lärare och elev (Doktorsavhandling). Göteborg: Acta Universitatis Gothoburgensis.

Ljungblad, A-L. (2016). Takt och hållning - en relationell studie om det oberäkneliga $i$ matematikundervisningen (Doktorsavhandling). Göteborg: Acta Universitatis Gothoburgensis.

Ljungblad, A-L. (2018). Relationellt lärarskap och pedagogiska möten. Lund: Studentlitteratur.

Ljungblad, A-L. (2019). Pedagogical relational teachership (PeRT) - A multi-relational perspective. International Fournal of Inclusive Education. https://doi.org/10.1080/13603116.2019.1581280

Ljungblad, A-L. \& Lennerstad, H. (2011). Matematik och respekt. Matematikens mångfald och lyssnandets konst. Stockholm: Liber.

Lövlie, L. (2007). Takt, humanitet och demokrati. I Y. Boman, C. Ljunggren \& M. von Wright (Red.), Erfarenheter av pragmatism (s. 77-104). Lund: Studentlitteratur.

Lövlie, L. (2015). Herbart om oppdragelse, formbarhet og takt. Nordisk tidsskrift for pedagogikk E kritikk, 1(1), 1-11. https://doi.org/10.17585/ntpk.v1.91

Manen van, M. (1991). The tact of teaching: The meaning of pedagogical thoughtfulness. London, Ontario: Althouse Press.

Manen van, M. (2015). Pedagogical tact. Walnut Creek: Left Coast Press. 


\section{Pedagogisk takt synliggör komplexiteten i läraryrkets relationella dimension}

Masschelein, J. (2011). Experimentum Scholae: The world once more... but not (yet) finished. Studies in Philosophy and Education, 30, 529-535. https://doi.org/10.1007/s11217-011-9257-4

Merleau-Ponty, M. (1962/2002). Phenomenology of perception. London: Routledge.

Rinne, I. (2014). Pedagogisk takt $i$ betygssamtal (Doktorsavhandling). Göteborg: Acta Universitatis Gothoburgensis.

Rinne, I. (2017). Relationella och emotionella aspekter av betygsättning. Pedagogisk forskning $i$ Sverige, 22(3-4), 166-183.

Roberts, P. (2020). More than measurement. Education, uncertainty and existence. I P. Howard, T. Saevi, A. Foran \& G. Biesta (Red.), Phenomenology and educational theory in conversation. Back to education itself. London: Routledge.

Saevi, T. \& Biesta, G. (2020) (Red.). Pedagogikk, periferi og verdi. Existentiell dialog om skole og samfunn. Bergen: Fagbokforlaget.

Schön, D. (1995). The reflective practitioner. How professionals think in action. Aldershot: Arena.

Säfström, C-A. (2005). Skillnadens pedagogik. Nya vägar $i$ den pedagogiska teorin. Lund: Studentlitteratur.

Thörgesen, U. (2003). Krop og fenomenologi. En introduktion til Maurice Merleau-Pontys filosofi. Köpenhamn: Systime Academic.

UD. (2006). Mänskliga rättigheter. Konventionen om barnets rättigheter. Rev. 05.059. Stockholm: Regeringskansliet. Uljens, M. (1998). Allmän pedagogik. Lund: Studentlitteratur.

Uljens, M. (2014). Människans tre födelser - om pedagogik, etik och politik. I M. Uljens (Red.), Pedagogik, filosofi och politik: Studier i pedagogisk handlingsteori (s. 24-57). Vasa: Åbo Akademi.

Uljens, M. (2017). Att teoretisera pedagogikens relationer. I H. Saeverot \& T. Werler (Red.), Pedagogikkens språk. Kunskapsformer i pedagogikkvitenskap (s. 62-87). Oslo: Gyldendal.

von Wright, M. (2000). Vad eller vem? En pedagogisk rekonstruktion av G. H. Meads teori om människors intersubjektivitet (Doktorsavhandling). Göteborg: Daidalos.

von Wright, M. (2006). The punctual fallacy of participation. Educational Philosophy and Theory, 38(2), 159-170. https://doi.org/10.1111/j.1469-5812.2006.00185.x 